\title{
Commentary \\ Trastuzumab, an appropriate first-line single-agent therapy for HER2-overexpressing metastatic breast cancer
}

\author{
Carlos L Arteaga
}

\begin{abstract}
Departments of Medicine and Cancer Biology, Vanderbilt University School of Medicine; and Breast Cancer Research Program, Vanderbilt-Ingram Comprehensive Cancer Center, Nashville, Tennessee, USA
\end{abstract}

Corresponding author: Carlos L Arteaga (e-mail: carlos.arteaga@vanderbilt.edu)

Received: 18 October 2002 Revisions received: 2 January 2003 Accepted: 16 January 2002 Published: 3 February 2003

Breast Cancer Res 2003, 5:96-100 (DOI 10.1186/bcr574)

(c) 2003 BioMed Central Ltd (Print ISSN 1465-5411; Online ISSN 1465-542X)

\begin{abstract}
Overexpression of the HER2/Neu (ErbB2) proto-oncogene is associated with breast cancer progression and poor patient prognosis. Herceptin (trastuzumab) is a humanized lgG1 against the ectodomain of the HER2 receptor. In combination with chemotherapy, it induces regression of HER2overexpressing metastatic breast tumors and prolongs patient survival. Single-agent Herceptin in patients with HER2-amplified breast tumors also induces a definite objective response and clinical benefit rates, and is well tolerated. These data suggest that Herceptin is an effective first-line singleagent therapy for a predictable cohort of metastatic breast cancers and can therefore be used as a platform for therapeutic discovery against tumors that overexpress HER2.
\end{abstract}

Keywords: breast cancer, clinical trials, erbB2, HER2/Neu, Herceptin

\section{Introduction}

The HER2/Neu proto-oncogene product is a member of the erbB family of transmembrane receptor tyrosine kinases, which also includes the epidermal growth factor receptor (EGFR, HER1, ErbB1), HER3 (ErbB3), and HER4 (ErbB4). Except for HER2, binding of receptor-specific ligands to the extracellular domain of EGFR, HER3, and HER4 results in the formation of homodimeric and heterodimeric phosphorylated, kinase-active complexes into which HER2 is recruited as a preferred partner [1-3]. Even though HER2 is unable to interact directly with HERactivating ligands, it can potentiate signaling by its coreceptors and/or increase the binding affinity of ligands to EGFR and HER3 (reviewed in [1]). Studies with HER2overexpressing breast cancer cell lines and human tumors have shown constitutive phosphorylation of HER2 [4,5]. The biochemical basis for this activation is not clear but it is consistent with the ability of wild-type $\mathrm{Neu}$, the rat homolog of human HER2, to multimerize and become activated in a ligand-independent fashion when present in cells at high density [6]. Overexpression of HER2 is associated with transformation of mammary epithelial cells
$[7,8]$ as well as shorter survival in patients with breast carcinoma $[9,10]$. The association of HER2 with poor patient prognosis, the ability to measure HER2 levels prospectively in diagnostic tumor tissue, and the lack of an apparent physiological role of HER2 in the adult, initially suggested this receptor as a rational therapeutic target in human breast cancer.

\section{Herceptin: mechanisms of action and clinical activity}

One therapeutic approach against HER2-overexpressing breast cancers is the generation of Herceptin (trastuzumab), a humanized IgG1 that binds to residues 529-626 in the HER2 ectodomain [11]. The mouse hybridoma counterpart of Herceptin, 4D5, partly removes HER2 from the plasma membrane $[12,13]$ and/or induces HER2 homodimerization (CL Arteaga, unpublished data), potentially preventing HER2 molecules from interacting with other HER co-receptors and thus impairing the growth of HER2-dependent tumor cells. A recent study demonstrated that Herceptin blocks the metalloprotease-induced cleavage of HER2 [14]. Proteolytic 
cleavage of HER2 results in the generation of a $95 \mathrm{kDa}$ amino-terminal membrane-associated fragment and shedding of the receptor's ectodomain [15]. The constitutive kinase activity of the $95 \mathrm{kDa}$ cytoplasmic fragment and the association of high levels of the shed HER2 ectodomain with poor patient outcome $[16,17]$ suggest that cleavage of HER2, potentially blocked by Herceptin, might be of clinical significance. Clynes and colleagues [18] reported that the inhibitory effect of the antibody against HER2-dependent xenografts is markedly abrogated in mice lacking the receptor FcyRIII, strongly implying that antibody-dependent, cell-mediated cytotoxicity (ADCC) is the predominant mechanism of action of the humanized IgG1. More recently, Yakes and colleagues [19] reported that, in HER2-overexpressing tumor cells, treatment with Herceptin results in inhibition of phosphoinositide 3-kinase (PI3K) and the serine/threonine kinase Akt. In that study, the antitumor effect of Herceptin was reversed by forced expression of activated Akt, suggesting that, in addition to immune mechanisms, the antibody might exert its antitumor effect by a blockade of PI3K/Akt signaling.

Although the mechanisms of action of Herceptin against patients' tumors remain to be elucidated, it has been shown to induce tumor regressions in up to $20 \%$ of heavily pretreated metastatic breast cancers $[20,21]$. Vogel and colleagues [22] recently reported the results of a clinical trial of single-agent Herceptin used as first-line therapy in 111 patients with metastatic breast tumors with high levels of HER2. Clinical responses were limited to tumors exhibiting HER2 overexpression or HER2 gene amplification as determined by $3+$ immunohistochemistry or excess copies of HER2 by fluorescence in situ hybridization (FISH), respectively. In this cohort, the objective response rate and the clinical benefit rate, as defined by stable disease lasting longer than 6 months, were a robust $35 \%$ and $48 \%$, respectively [22]. Although an accurate assessment of the median duration of clinical response was not possible because of patient censoring, $57 \%$ of the responding patients were free of disease progression at more than 12 months of follow-up, underscoring the durability of the responses. Remarkably, the median duration of survival for all enrolled patients was 24.4 months, almost identical to the 25.1 months median survival of patients with HER2-overexpressing metastatic breast tumors treated with chemotherapy and Herceptin in a previous study [23]. Taken together, these clinical data confirm a role for HER2 in the progression of human breast carcinomas. They also suggest that a cohort of breast cancers remain HER2-dependent until advanced metastatic phases of the disease. In addition, high levels of HER2 protein overexpression and/or HER2 gene amplification accurately predict reasonable odds of response to Herceptin and can therefore be used for rational patient selection with this molecule-directed therapy.

\section{Rationale for future clinical directions}

The rate of HER2 gene amplification in ductal carcinoma in situ (DCIS) of the breast is the same as or higher than that in metastatic breast cancer [24-26]. Because DCIS is a well-established precursor of invasive breast cancer [27], this suggests that HER2 overexpression occurs years before the onset of advanced invasive carcinoma. The progression of DCIS to invasive and late metastatic cancer is inexorably associated with the accumulation of additional genetic alterations. On the basis of these data, one could speculate on two possibilities. First, the results of the study by Vogel and colleagues [22] might be better than could have been expected as they suggest that a cohort of metastatic breast cancers, namely the Herceptin responders, remain predominantly dependent on HER2 function until late phases in the natural history of the disease. Such a magnitude of clinical response might not necessarily apply to the inactivation of other cancer targets with single molecular therapies. Second, it would be expected that the efficacy and curative potential of Herceptin would increase if used in earlier phases of the disease and/or in patients with lower tumor burden, that is, for the prevention of progression of preinvasive cancers or for the treatment of subclinical micrometastases in the adjuvant setting. Several clinical trials with Herceptin in the adjuvant setting in HER2-overexpressing breast cancers are under way worldwide. It is envisaged that enrollment into these large adjuvant trials and the potential general use of Herceptin in the adjuvant setting will change the natural history of HER2-amplified breast carcinoma. As these trials continue to enroll patients, one could expect a decrease in the overall percentage of metastatic breast tumors diagnosed de novo that express high levels of the proto-oncogene.

Slamon and colleagues [23] reported the ability of Herceptin to increase the clinical benefit from first-line chemotherapy against metastatic breast cancers that overexpress HER2. These ground-breaking studies documented a $25 \%$ improvement in survival in patients that received concurrent Herceptin and chemotherapy compared with chemotherapy alone. Interestingly, however, the median survival (25.1 months) of patients in this trial receiving the combination was almost identical to the 24.4-month median survival of patients enrolled in the single-agent Herceptin trial performed by Vogel and colleagues [22]. In both of these studies, the eligibility was similar whereas Herceptin was much better tolerated in the single-agent trial than was the combination of chemotherapy plus antibody in the study by Slamon and colleagues. Although one cannot exclude referral biases that might have resulted in different patient populations in these two trials, the published demographics for the subjects enrolled in these studies indicate that they were similar when compared by age, performance status, percentage of steroid receptor-positive tumors, number of 
metastatic sites, and prior adjuvant chemotherapy. If these HER2-overexpressing patient cohorts were similar, as the patients' published characteristics would support, this might suggest, first, that in the combination therapy study the antitumor effect was mainly due to Herceptin, and, second, that Herceptin is a reasonable first-line single agent in oligosymptomatic patients that fit the eligibility of the study by Vogel and colleagues and can be used as a platform onto which other molecular therapies, not necessarily chemotherapy, can be added. Those added therapies would be those that target molecules or mechanisms of de novo or acquired Herceptin resistance.

\section{Therapeutic resistance}

Most metastatic breast tumors with HER2 gene amplification and/or very high levels of HER2 protein do not respond to Herceptin, suggesting the possibility that in most late breast cancers, HER2 has become dispensable for tumor viability and progression. This fact, together with the frequent overexpression of HER2 in non-invasive disease and the eventual escape from Herceptin action in patients with HER2-amplified metastatic breast cancers, suggests de novo and acquired mechanisms of therapeutic resistance. The antitumor effect of HER2 inhibitors such as Herceptin would require the subversion of key post-receptor signaling pathways and cell cycle/anti-apoptosis regulatory molecules that mediate the transforming effects of HER2. These post-receptor pathways are shared with heterologous receptor networks $[28,29]$ and/or with heterodimers of the same HER (ErbB) network that are not affected by Herceptin. These data therefore imply that tumor cells are intrinsically endowed with signaling mechanisms of compensation that can counteract the blockade of HER2 function by single-agent Herceptin.

The mechanisms of de novo or acquired resistance to Herceptin are not yet known. However, recent reports suggest some possibilities. Indeed, overexpression of the IGF-I receptor abrogates the effect of Herceptin against HER2-overexpressing SKBR-3 cells. Addition of the IGF-I receptor antibody $\alpha$ IR3 or IGF-BP3 reverses Herceptin resistance [30]. Herceptin potently inhibits PI3K and Akt in HER2-dependent, antibody-sensitive cells [19,31]. Conversely, Herceptin neither decreases PI3K activity nor inhibits the growth of HER2-overexpressing MKN gastric cancer cells [32]. Transduction of vectors encoding activated Akt prevents the Herceptin-induced inhibition of proliferation of BT-474 cells and apoptosis in SKBR-3 cells [19]. These data suggest that inhibition of PI3K/Akt signaling is required for the antitumor effect of HER2 inhibitors such as Herceptin. Many breast cancers harbor genetic alterations resulting in aberrant $\mathrm{PI} 3 \mathrm{~K} / \mathrm{Akt}$ signaling or overexpress heterologous receptor networks, such as IGF-IR, that potently activate PI3K/Akt. We speculate that these coexisting alterations in HER2-overexpressing breast basis of these data, a combined therapeutic approach with HER2 and PI3K/Akt inhibitors would be worth investigating in these tumors.

High levels of activated EGFR abrogate the efficacy of Herceptin against HER2-gene-amplified cancer cells [32] and this resistance is reversed by ATP-competitive inhibitors of the EGFR tyrosine kinase [33]. In addition, the EGFR antibody C225 synergizes with 4D5 against HER2-overexpressing ovarian cancer cells [34]. Moreover, the EGFR kinase inhibitor ZD1839 inhibits HER2 phosphorylation by itself and potentiates the antitumor effect of Herceptin against breast cancer xenografts [35-37]. Taken together these results suggest, first, that activated EGFR can potentially mediate escape from Herceptin action, and second, that combinations of Herceptin with EGFR inhibitors are synergistic against HER2-overexpressing tumors that also express EGFR. This hypothesis is currently being tested in phase II studies of Herceptin in combination with the EGFR kinase inhibitors ZD1839 or OSI-774.

Another approach that might shed light on mechanisms of Herceptin resistance is the sequencing of the HER2 gene from tumors known to be progressing on Herceptin therapy. It should be emphasized that the studies documenting a lack of somatic mutations of HER2 in primary breast cancers [38] predate the development and use of Herceptin. Thus, the possibility of acquired HER2 mutations as a result of the selective pressure of HER2 blockade has never been explored and is worth revisiting in breast cancers 'selected' for Herceptin resistance in vivo.

Finally, one possible exploratory trial design to address resistance mechanisms would be the administration of neoadjuvant Herceptin followed by chemotherapy to newly diagnosed HER2 gene-amplified tumors. Herceptin can be started as a single agent for the first 4 weeks before the addition of chemotherapy, while tumor core biopsies are obtained weekly. This approach has been used effectively with antiestrogens. These studies have shown that as little as 14 days of therapy with tamoxifen results in a marked reduction of breast cancer cell proliferation as measured by Ki67 immunohistochemistry of tumor sections but this reduction was limited to estrogen-receptor-positive tumors [39-41]. Any excess tissue from the initial and follow-up core biopsies can be used to detect novel RNAs or proteins and their changes as a function of inhibition of cell proliferation and/or inhibition of cell survival after treatment with Herceptin. These two endpoints will be measured by Ki67 immunohistochemistry and TUNEL (terminal transferase deoxytidyl uridine end labeling), respectively. By focusing on differences in dynamic changes on RNA and/or protein expression profiles between responders and non-responders, this approach should detect markers of resistance to Herceptin and/or mechanisms causally associated with the resistant phenotype. 


\section{Summary}

The data summarized above clearly imply that Herceptin is an effective first-line single-agent therapy for HER2-overexpressing metastatic breast cancers. Herceptin can be used as a platform onto which other molecular therapies, perhaps those targeting molecules that mediate de novo or acquired escape from the HER2 inhibitor, can be added. Because Herceptin is well tolerated, scientifically rational combinations of the antibody with other moleculetargeted drugs are medically justifiable as first-line therapy in metastatic disease. Whether giving Herceptin alone as initial therapy jeopardizes subsequent survival in response to treatment with Herceptin and chemotherapy requires further investigation. Elucidation of the preferential molecular mechanisms of escape from Herceptin and/or HER2 dependence will define new rational targets against which drugs either are available or are to be developed. Drugs against these targets can be combined with Herceptin to prevent de novo or acquired resistance and to enhance therapeutic efficacy. If tumor-specific and well tolerated, combinations of anti-signaling drugs that include Herceptin should become a robust therapeutic alternative to non-specific cytotoxic chemotherapy against HER2-overexpressing breast carcinoma.

\section{Competing interests}

CLA has received consultation honoraria and grant support from Genentech, Inc.

\section{Acknowledgement}

Supported by NCl grant R01 CA80195 and Vanderbilt-Ingram Cancer Center support grant CA68485.

\section{References}

1. Yarden $\mathrm{Y}$, Sliwkowski $M X$ : Untangling the ErbB signalling network. Nat Rev Mol Cell Biol 2001, 2:127-137.

2. Olayioye MA, Neve RM, Lane HA, Hynes NE: The ErbB signaling network: receptor heterodimerization in development and cancer. EMBO J 2000, 19:3159-3167.

3. Graus-Porta D, Beerli RR, Daly JM, Hynes NE: ErbB-2, the preferred heterodimerization partner of all ErbB receptors, is a mediator of lateral signaling. EMBO J 1997, 16:1647-1655.

4. Alimandi M, Romano A, Curia MC, Muraro R, Fedi $\mathrm{P}$, Aaronson SA, Di Fiore PP, Kraus MH: Cooperative signaling of ErbB3 and ErbB2 in neoplastic transformation and human mammary carcinomas. Oncogene 1995, 10:1813-1821.

5. Thor AD, Liu S, Edgerton S, Moore D, Kasowitz KM, Benz CC, Stern DF, DiGiovanna MP: Activation (tyrosine phosphorylation) of ErbB-2 (HER-2/neu): a study of incidence and correlation with outcome in breast cancer. J Clin Oncol 2000, 18:3230-3239.

6. Samanta A, LeVea CM, Dougall WC, Qian X, Greene MI: Ligand and p185c-neu density govern receptor interactions and tyrosine kinase activation. Proc Natl Acad Sci USA 1994, 91:17111715.

7. Pierce JH, Arnstein P, DiMarco E, Artrip J, Kraus MH, Lonardo F, Di Fiore PP, Aaronson SA: Oncogenic potential of erbB-2 in human mammary epithelial cells. Oncogene 1991, 6:11891194.

8. Muthuswamy SK, Li D, Lelievre S, Bissell MJ, Brugge JS: ErbB2, but not ErbB1, reinitiates proliferation and induces luminal repopulation in epithelial acini. Nat Cell Bio/ 2001, 3:785-792.

9. Slamon DJ, Godolphin W, Jones LA, Holt JA, Wong SG, Keith DE, Levin WJ, Stuart SG, Udove J, Ullrich A, et al.: Studies of the HER-2/neu proto-oncogene in human breast and ovarian cancer. Science 1989, 244:707-712.
10. Ross JS, Fletcher JA: The HER-2/neu oncogene in breast cancer: prognostic factor, predictive factor, and target for therapy. Stem Cel/s 16:413-428, 1998.

11. Carter P, Presta L, Gorman CM, Ridgway JB, Henner D, Wong WL, Rowland AM, Kotts C, Carver ME, Shepard HM: Humanization of an anti-p185HER2 antibody for human cancer therapy. Proc Natl Acad Sci USA 1992, 89:4285-4289.

12. Hudziak RM, Lewis GD, Winget M, Fendly BM, Shepard HM, Ullrich A: p185HER2 monoclonal antibody has antiproliferative effects in vitro and sensitizes human breast tumor cells to tumor necrosis factor. Mol Cell Biol 1989, 9:1165-1172.

13. De Santes K, Slamon D, Anderson SK, Shepard M, Fendly B, Maneval D, Press O: Radiolabeled antibody targeting of the HER-2/neu oncoprotein. Cancer Res 1992, 52:1916-1923.

14. Molina MA, Codony-Servat J, Albanell J, Rojo F, Arribas J, Baselga $\mathrm{J}$ : Trastuzumab (Herceptin), a humanized anti-Her2 receptor monoclonal antibody, inhibits basal and activated Her2 ectodomain cleavage in breast cancer cells. Cancer Res 2001, 61:4744-4749.

15. Christianson TA, Doherty JK, Lin YJ, Ramsey EE, Holmes R, Keenan EJ, Clinton GM: $\mathrm{NH}_{2}$-terminally truncated HER-2/neu protein: relationship with shedding of the extracellular domain and with prognostic factors in breast cancer. Cancer Res 1998, 58:5123-5129.

16. Colomer R, Montero S, Lluch A, Ojeda B, Barnadas A, Casado A, Massuti B, Cortes-Funes H, Lloveras B: Circulating HER2 extracellular domain and resistance to chemotherapy in advanced breast cancer. Clin Cancer Res 2000, 6:2356-2362.

17. Leitzel K, Teramoto Y, Konrad K, Chinchilli VM, Volas G, Grossberg $\mathrm{H}$, Harvey H, Demers L, Lipton A: Elevated serum c-erbB-2 antigen levels and decreased response to hormone therapy of breast cancer. J Clin Oncol 1995, 13:1129-1135.

18. Clynes RA, Towers TL, Presta LG, Ravetch JV: Inhibitory Fc receptors modulate in vivo cytoxicity against tumor targets. Nat Med 2000, 6:443-446.

19. Yakes FM, Chinratanalab W, Ritter CA, King W, Seelig S, Arteaga CL: Herceptin-induced inhibition of phosphatidylinositol-3 kinase and Akt is required for antibody-mediated effects on p27, cyclin D1, and antitumor action. Cancer Res 2002, 62:4132-4141.

20. Baselga J, Tripathy D, Mendelsohn J, Baughman S, Benz CC, Dantis L, Sklarin NT, Seidman AD, Hudis CA, Moore J, Rosen PP, Twaddell T, Henderson IC, Norton L: Phase II study of weekly intravenous recombinant humanized anti-p185HER2 monoclonal antibody in patients with HER2/neu-overexpressing metastatic breast cancer. J Clin Oncol 1996, 14:737-744.

21. Cobleigh MA, Vogel CL, Tripathy D, Robert NJ, Scholl S, Fehrenbacher L, Wolter JM, Paton V, Shak S, Lieberman G, Slamon DJ: Multinational study of the efficacy and safety of humanized anti-HER2 monoclonal antibody in women who have HER2overexpressing metastatic breast cancer that has progressed after chemotherapy for metastatic disease. J Clin Oncol 1999, 17:2639-2648.

22. Vogel CL, Cobleigh MA, Tripathy D, Gutheil JC, Harris LN, Fehrenbacher L, Slamon DJ, Murphy M, Novotny WF, Burchmore M, Shak S, Stewart SJ, Press M: Efficacy and safety of Trastuzumab as a single agent in first-line treatment of HER2overexpressing metastatic breast cancer. J Clin Oncol 2002, 20:719-726

23. Slamon DJ, Leyland-Jones B, Shak S, Fuchs H, Paton V, Bajamonde A, Fleming T, Eiermann W, Wolter J, Pegram M, Baselga J, Norton L: Use of chemotherapy plus a monoclonal antibody against HER2 for metastatic breast cancer that overexpresses HER2. N Engl J Med 2001, 344:783-792.

24. van de Vijver MJ, Peterse JL, Mooi WJ, Wisman P, Lomans J, Dalesio O, Nusse R: Neu-protein overexpression in breast cancer. Association with comedo-type ductal carcinoma in situ and limited prognostic value in stage II breast cancer. $N$ Engl J Med 1988, 319:1239-1245.

25. Allred DC, Clark GM, Molina R, Tandon AK, Schnitt SJ, Gilchrist KW, Osborne CK, Tormey DC, McGuire WL: Overexpression of HER-2/neu and its relationship with other prognostic factors change during the progression of in situ to invasive breast cancer. Hum Pathol 1992, 23:974-979.

26. Glockner S, Lehmann U, Wilke N, Kleeberger W, Langer F, Kreipe $\mathrm{H}$ : Amplification of growth regulatory genes in intraductal breast cancer is associated with higher nuclear grade but not 
with the progression to invasiveness. Lab Invest 2001, 81:565571.

27. O'Connell P, Pekkel V, Fuqua SA, Osborne CK, Clark GM, Allred DC: Analysis of loss of heterozygosity in 399 premalignant breast lesions at 15 genetic loci. J Natl Cancer Inst 1998, 90:697-703.

28. Carpenter G: Employment of the epidermal growth factor receptor in growth factor-independent signaling pathways. J Cell Biol 1999, 146:697-702.

29. Gschwind A, Zwick E, Prenzel N, Leserer M, Ullrich A: Cell communication networks: epidermal growth factor receptor transactivation as the paradigm for interreceptor signal transmission. Oncogene 2001, 20:1594-1600.

30. Lu Y, Zi X, Zhao Y, Mascarenhas D, Pollak M: Insulin-like growth factor-I receptor signaling and resistance to trastuzumab (Herceptin). J Natl Cancer Inst 2001, 93:1852-1857.

31. Hermanto $U$, Zong CS, Wang LH: ErbB2-overexpressing human mammary carcinoma cells display an increased requirement for the phosphatidylinositol 3-kinase signaling pathway in anchorage-independent growth. Oncogene 2001, 20:7551-7562

32. Lane HA, Beuvink I, Motoyama AB, Daly JM, Neve RM, Hynes NE: ErbB2 potentiates breast tumor proliferation through modulation of p27(Kip1)-Cdk2 complex formation: receptor overexpression does not determine growth dependency. Mol Cell Bio/ 2000, 20:3210-3223.

33. Motoyama AB, Hynes NE, Lane HA: The efficacy of ErbB receptor targeted anti-cancer therapeutics is influenced by the availability of EGF-related peptides. Cancer Res 2002, 62:3151-3158.

34. Ye D, Mendelsohn J, Fan Z: Augmentation of a humanized antiHER2 mAb 4D5 induced growth inhibition by a human-mouse chimeric anti-EGF receptor mAb C225. Oncogene 1999, 18:731-738.

35. Moasser MM, Basso A, Averbuch SD, Rosen N: The tyrosine kinase inhibitor ZD1839 ('Iressa') inhibits HER2-driven signaling and suppresses the growth of HER2-overexpressing tumor cells. Cancer Res 2001, 61:7184-7188.

36. Moulder SL, Yakes FM, Muthuswamy SK, Bianco R, Simpson JF, Arteaga CL: Epidermal growth factor receptor (HER1) tyrosine kinase inhibitor (Iressa) inhibits HER2/neu (erbB2)-overexpressing breast cancer cells in vitro and in vivo. Cancer Res 2001, 61:8887-8895

37. Anderson NG, Ahmad T, Chan K, Dobson R, Bundred NJ: ZD1839 (Iressa), a novel epidermal growth factor receptor (EGFR) tyrosine kinase inhibitor, potently inhibits the growth of EGFR-positive cancer cell lines with or without erbB2 overexpression. Int J Cancer 2001, 94:774-782.

38. Lemoine NR, Staddon S, Dickson C, Barnes DM, Gullick WJ: Absence of activating transmembrane mutations in the cerbB-2 proto- oncogene in human breast cancer. Oncogene 1990, 5:237-239.

39. Ellis PA, Saccani-Jotti G, Clarke R, Johnston SR, Anderson E, Howell A, A'Hern R, Salter J, Detre S, Nicholson R, Robertson J, Smith IE, Dowsett M: Induction of apoptosis by tamoxifen and ICl 182780 in primary breast cancer. Int J Cancer 1997, 72:608-613.

40. Chang J, Powles TJ, Allred DC, Ashley SE, Makris A, Gregory RK, Osborne CK, Dowsett M: Prediction of clinical outcome from primary tamoxifen by expression of biologic markers in breast cancer patients. Clin Cancer Res 2000, 6:616-621.

41. Robertson JF, Nicholson RI, Bundred NJ, Anderson E, Rayter Z, Dowsett M, Fox JN, Gee JM, Webster A, Wakeling AE, Morris $C$, Dixon M: Comparison of the short-term biological effects of $7 \alpha-[9-(4,4,5,5,5$-pentafluoropentylsulfinyl)-nonyl]estra-1, 3,5,(10)-triene-3,17 $\beta$-diol (Faslodex) versus tamoxifen in postmenopausal women with primary breast cancer. Cancer Res 2001, 61:6739-6746.

\section{Correspondence}

Carlos L Arteaga MD, Division of Oncology, Vanderbilt University Medical Center, 2220 Pierce Avenue, 777 PRB, Nashville, TN 37232 6307, USA. Tel: +1 615936 3524; Fax: +1615936 1790; e-mail: carlos.arteaga@vanderbilt.edu 